\title{
Insecticidal Activity of Commercial Oil and Petroleum Ether Extract of Clove Buds (Syzygium aromaticum) on Some Stored Grain Pests.
}

\author{
Doaa M. Boraie*; Hala H. Al-Akhdar ${ }^{* *}$ and Mariam G. Sadek ${ }^{* *}$ \\ "Stored Products and Grains Department, Plant Protection Res. Institute, Agric. Res. Center. Dokki, Giza, Egypt. \\ ${ }^{* *}$ Crops and Cotton Mites Department, Plant Protection Res. Institute, Agric. Res. Center. Dokki, Giza, Egypt.
}

\begin{abstract}
This study aimed to evaluate the insecticidal activity of commercial clove oil and clove petroleum ether extract (Syzygium aromaticum) on the adults of rice weevil, Sitophilus oryzae (L.); cowpea beetle, Callosobruchus maculatus (F.); red flour beetle, Triboleum casteneum $(\mathrm{H}$.) ; the mould mite, Tyrophagus putrescentiae (Shrank) and Dermatophagoides farinae (Shrank) at $30 \pm 2^{\circ} \mathrm{C}$ and $65 \pm 5 \%$ R.H. Besides, studying the efficacy of clove petroleum ether extract to protect grains during storage and if it had any effect on seeds germination plus analyzing the chemical constituents for both extract and commercial oil through GC/MS technique to study the difference in main constituents. Results showed complete mortality $(\%)$ at the highest concentration with S.oryzae, C.maculatus and T.putrescentiae while T.casteneum and D. farinae showed high resistance for both oil and extract. Accumulative mortality of pests increased gradually with the increase of concentrations and exposure period. The reproduction of females of all experimental pests was completely inhibited at the highest concentration. T. castaneum was less susceptible to tested oils compared with S.oryzae and C.maculatus. The extract was more powerful than commercial oil especially with T.casteneum and $D$. farinae which are known to have high resistance. Clove extract give complete protection for grains for 10 weeks with low significant on germination (\%). The main constituents of clove commercial oil were eugenol (50.58\%), cinnamaldehyde (15.72\%) and linoleic acid $(9.52 \%)$ and those of the clove extract were eugenol $(37.43 \%)$ eugenol acetate $(11.47 \%)$, caryophellene $(10.44 \%)$, linoleic acid $(9.42 \%)$ and caryophellene oxide $(8.58 \%)$.
\end{abstract}

Key words: stored grain pests, clove oil, germination of seeds, Clove extract, residual toxicity and mites.

\section{INTRODUCTION}

There is increasing interest both in industry and scientific research for aromatic and medicinal plants because of their potential applications in medicine and plant disease control measures. The antimicrobial, antifungal and insecticidal properties of plant essential oils are well established against wide spectra of organisms such as fungi, bacteria and insects. These properties are mainly due to many active phytochemicals including vitamins, flavanoids, terpenoids, carotenoids, coumarins, curcumines, etc. and hence, they are of great importance in food industry and offer the possibility to substitute natural sources for synthetic preservatives and other products, (Gurdip and Sumitra, 2005).

Pests of stored grains include rice weevil, Sitophilus oryzae (L.); red floor beetle, Tribolium castaneum; cowpea beetle, Callosobruchus maculatus and the mould mite, Tyrophagus putrescentiae, (Park et al., 2003; Demitry et al., 2007 \& Li, 2004).

The bioactivity of clove oil and extract as pest control agents against stored grain pests was studied by many investigators, (Lee et al., 2001; Mahfuz and Khalequzzaman,2007; Sumadi et al., 2010; Zeng, et $a l ., 2010$ \& Khalequzzaman and Rumu, 2010).

The main chemical constituent of clove oil is eugenol which represents about $74.3 \%$ (Alma et al., 2007; Ayoolal et al., 2008 \& Nazrul et al.,2010) and known as powerful insecticide ( Kwon Park and SangChul Shin 2005 \& Zeng et al., 2010) .
Many researchers used commercial oils to prove its effectiveness against stored grain pests, therefore, this research aims to study the differences of toxicity between commercial oil and oil extract in the laboratory, also to study the effect of clove oil extracts in laboratory to protect seeds during storage.

\section{MATERIALS AND METHODS}

\section{1) REARING:}

\section{1-A) INSECT REARING:}

Tested insects were reared in glass jars (each of approximately $500 \mathrm{ml}$ ) containing about $250 \mathrm{gm}$ of cowpea and wheat seeds. Each jar was covered with muslin cloths and fixed with rubber bands for egg laying and incubated at $30 \pm 2^{\circ} \mathrm{C}$ and $65 \pm 5 \%$ R.H.

\section{1-B) MITE REARING:}

Strains of mould mites, Tyrophagus putrescentiae and Dermatophagoides farinae were collected from infested wheat samples for obtaining a pure culture, adults were placed in rearing plastic rings containing yeast for feeding at $30 \pm 2{ }^{\circ} \mathrm{C}$ and $65 \pm 5 \%$ R.H.

\section{2) BIOASSAY TESTS: \\ 2-a) PLANT EXTRACTS:}

To obtain the plant extracts, 500 gm of clove buds (Syzygium aromaticum) was ground in an electric mill into fine powder then soaked in petroleum ether solvent in a large flask for 5 days. The flask was shacked for one hour in a shaker and its content was filtered. The solvent was evaporated at $50^{\circ} \mathrm{c}$ under reduced pressure using a rotary evaporator as 
described by (Su, 1985). The extract in the form of a crude gum was weighted and dissolved by the same solvent to get $10 \% \quad(\mathrm{w} / \mathrm{v})$ stock solution. Concentrations of $3,2,1,0.5,0.25$ and $0.125(\mathrm{w} / \mathrm{v})$ were prepared by diluting the stock solution.

To investigate the effect of clove extract on three insects, S. oryzae, T. casteneum, C. maculatus and two mite species, Tyrophagus putrescentiae and Dermatophagoides farinae, about 10 grams of wheat and cowpea seeds were put separately into glass jars of $50 \mathrm{ml}$, mixed with clove extract and left for dryness (for 24hrs). Twenty adult insects (1-2 week old $S$. oryzae and $T$. casteneum) and (1-24 hrs old mites, $T$. putrescentiae and $D$. farinae) were confined with treated wheat seeds and (1-24 hrs old C.maculatus) was confined with the treated cowpea seeds. Jars were covered with muslin fixed with rubber bands and kept at $30 \pm 2^{\circ} \mathrm{C}$ and $65 \pm 5 \%$ R.H. Every treatment was replicated three times. A set of jars contained untreated seeds were used as control.

To evaluate the efficacy of clove extract on tested pests, the mortality percentages were estimated after $2,3,5,7$ and 10 days of exposure for S. oryzae and T. casteneum; while for $C$. maculatus after 1, 2, 3, 4, 5 days and after 1, 3, 5, 7 days for mites. Mortality percentages were corrected using Abbot's formula (1925). The number of offspring (progeny) was also determined after 35 days from treatment for C.maculatus and after 65 days for S.oryzae and T. casteneum.

Reduction percentages in progeny of offspring were calculated by the following equation (El-Lakwah et al., 1996).

$$
\begin{aligned}
\% \text { reduction }= & \{(\text { Offspring emerged in control }- \text { offspring } \\
& \text { emerged in treatment }) / \text { Offspring emerged } \\
& \text { in control }\} \times 100
\end{aligned}
$$

\section{2-b) Commercial oil:}

Samples of 10 grams of each of cowpea and wheat seeds were mixed with four different concentrations; 2, 4, 6 and $8 \mathrm{mg} / \mathrm{kg}$ of oil. Three replicates were used for each concentration. The jars were covered with muslin and sealed with rubber bands, and kept for $48 \mathrm{hrs}$ at room temperature for oil adsorption. Three replicates of non treated seeds were made as control. Twenty adult insects (1- 2 weeks old $S$. oryzae and $T$. casteneum) and (1-24 hrs old mites, T. putrescentiae and $D$. farinae) were confined with the treated wheat seeds and (1-24 hrs old C. maculatus) confined with the treated cowpea seeds. Jars were covered with muslin fixed with rubber bands and kept at $30 \pm 2^{\circ} \mathrm{Cand}$ $65 \pm 5 \%$ R.H. Mortality (\%) counts were calculated as mentioned before. Reduction percentage in progeny of offspring was calculated.

\section{3) DATA ANALYSIS}

The mortality of the tested pest adults was probit analyzed using a computer program named ldp-line according to Finney (1971), from which the toxicity values $\left(\mathrm{Lc}_{50}\right.$ and $\left.\mathrm{Lc}_{95}\right)$ and Slope values of the tested compounds were estimated.

\section{4) RESIDUAL TOXICITY STUDIES: \\ 4-a) PERSISTANCE TESTS:}

To study the residual efficacy of clove extract against $C$. maculatus and $S$. oryzae; $\mathrm{LC}_{95}$ conc. was mixed separately with $100 \mathrm{gm}$ of cowpea and wheat seeds and stored for 10 weeks under laboratory conditions. One hundred gm of untreated seeds were used for control. Three replicates were used for each group. Five gm of each treated and untreated seeds were placed into a glass pot and infested with 5 pairs of insects. Three replicates were used for each group. The mortality percentages of insects after 5 days of treatment and reduction in $\mathrm{F}_{1}$-progeny after 35 (for $C$. maculatus) and 65 days (for S. oryzae) were recorded. The toxicity was tested every week.

\section{4-b) SEED GERMINATION TEST:}

The germination of treated seeds with $\mathrm{LC}_{95}$ conc. and control seeds was tested after 24 hours and 10 weeks from storage. For this assay, 20 seeds from each treated and untreated replicate were placed separately in Petri dish, under laboratory conditions but without insects. The germination of seeds was evaluated for each treatment. Each group of seeds was placed on moist filter paper in Petri dishes and incubated at $25^{\circ} \mathrm{C}$.

\section{5) GC/MS CHROMATOGRAM:}

The chemical constituents of both clove extract and commercial oil were identified by GC/MS (Gas chromatography-mass spectrometry) gas chromatograph equipped with an agilent mass spectrometric detector, with a direct capillary interface and fused silica capillary column pas- $5 \mathrm{~ms}$ ( $30 \mathrm{~mm} \times 0.25$ um film thickness). Samples were injected under the following conditions:

Helium was used as carrier gas at approximately $1 \mathrm{ml} / \mathrm{min}$., pulsed splitless mode. The solvent delay was $3 \mathrm{~min}$. and the injection size was $1.0 \mathrm{ul}$. The mass spectrophotometric detector was operated in electron impact ionization mode ionizing energy 70 e.v. scanning from $\mathrm{m} / \mathrm{z} 50$ to 500 . The ion source temperature was $230^{\circ} \mathrm{C}$ and the quadrupole temperature was $150^{\circ} \mathrm{C}$. The electron multiplier voltage (EM voltage) was maintained $1250 \mathrm{~V}$ above auto tune. The instrument was manually tuned using perfluorotributyl amine (PFTBA). The $\mathrm{GC}$ temperature program was started at $60^{\circ} \mathrm{C}$ then elevated to $280^{\circ} \mathrm{C}$ at rate of $8 \mathrm{c} / \mathrm{min}$, and $10 \mathrm{~min}$. hold at $280^{\circ} \mathrm{C}$ the detector and injector temperature were set at $280^{\circ} \mathrm{C}$ and $250^{\circ} \mathrm{C}$, respectively. 
Identification of the compounds:

Compound identification was made by comparing the NIST and WILEY libraries and with the authentic spectra (Adams, 1995). Data of the peaks with those reported in literature, mass spectra of the peaks with literature data. Percentage composition was computed from GC peak areas on BP-I column without applying correction factors.

\section{RESULTS AND DISCUSSION}

Results in tables 1,2 and 3 indicated that the mortality rate increased with the increasing of concentration and exposure period with both the commercial oil and the extract. Both extract and oil have high insecticidal activity against $C$. maculatus and $S$. oryzae causing $100 \%$ mortality with the highest conc. at the end of the experiment; while with $T$. casteneum the extract caused $70 \%$ at the highest conc. and show high resistance to commercial oil.

Both oil and extract gave $100 \%$ reduction in $\mathrm{F}_{1}$ - progeny at most tested concentrations with $C$. maculatus and $S$. oryzae. Although the oil and extract were not powerful against T.casteneum they caused $100 \%$ reduction in $F_{1}$ - progeny with the highest concentration.

These results were in harmony with those obtained by Abd El-Salam (2010), who tested the fumigant toxicity of clove oil on both C.maculatus and S. oryzae and found that the oil gave high mortality values; C.maculatus was more susceptible to the oil than S. oryzae. Fouad (2013a), who found that, clove oil, repelled all C.maculatus adults at $1 \%$ conc. Mondal and Khalequzzaman (2006), found that the clove oil didn't give high mortality values at LC50 concentration with adults and larvae of T.casteneum in both contact and fumigant bioassay. Zeng et al., (2010), found that clove oil and its two main chemical constituents 2methoxy-4-(2-propenyl)-phenol and transcaryophyllene gave high toxicity and repellency grade with $R$. dominica, S.oryzae and $T$. castaneum. Mahfuz and Khalequzzaman (2007) tested 5 essential oils against Callosobruchus maculatus and found that the toxicity of the oils followed in the order: eucalyptus $>$ clove $>$ cinnamon $>$ cardamom $>$ neem. In the fumigation bioassay after 24 and $48 \mathrm{~h}$ of treatments. Mishra et al., 2014 screened the chronic activity of clove oil against rice weevil Sitophilus oryzae
(Coleoptera: Curculionidae) in laboratory assay and showed that fumigation with sub-lethal concentration of essential oil significantly $(p<0.01)$ reduced oviposition and exhibited ovicidal activity. Fouad (2013b) found that clove oil had high repellency rate at $4 \%$ concentration against the faba bean beetle Bruchidius incarnates. Mahdi and Khaladur Rahman (2008) recorded that clove oil was effective as protectant of black gram seeds against the pulse beetle, Callosobruchus maculatus (F.). Sabbour and Abd-El-Aziz (2009) tested clove oil against Bruchidius incarnates and recorded it as a strong repellent after 7 days from treatment.

As shown in tables 4 and 5 , mortality rate increased with increasing of concentration and exposure period. Both oil and extract were powerful against the mould mite, $T$. putrescentiae; while with $D$. farinae the extract showed high mortality compared with commercial oil.

This result agreed with the results of kim et al., 2003b who tested the acaricidal activity of clove bud oil compounds (acetyleugenol, vcaryophyllene, eugenol, a-humulene), and congeners of eugenol (isoeugenol, methyleugenol) against adult Tyrophagus putrescentiae and found that in fumigation tests with adult $T$. putrescentiae, all four phenylpropenes were more effective against the mite in closed containers than in open ones, indicating that the mode of delivery of these compounds was largely due to action in the vapor phase. Pumnuan and Insung (2011) who investigated the acaricidal activity of essential oils obtained from 28 selected medicinal plants against stored product mite, Suidasia pontifica Oudemans and found that at the dose of $1.0 \%$, essential oils of clove (Syzygium aromaticum), cinnamon (Cinnamomum bejolghota), myrtle grass (Acorus calamus), betel vine (Piper betle), and turmeric (Curcuma longa) were highly toxic to $S$. pontifica with more than $70 \%$ mite mortality. Kim et al., 2003a examined the acaricidal activity of clove (Syzygium aromaticum) bud oil-derived eugenol and its congeners (acetyleugenol, isoeugenol, and methyleugenol) against adults of Dermatophagoides farinae using direct contact application and fumigation methods. They found that on the basis of $\mathrm{LD}(50)$ values, the compound 
Table (1): Toxicity of both clove oil and extract on S.oryzae adults infesting wheat seeds

\begin{tabular}{|c|c|c|c|c|c|c|c|c|}
\hline \multirow{2}{*}{$\begin{array}{l}\text { Tested } \\
\text { material }\end{array}$} & \multirow{2}{*}{$\begin{array}{c}\text { Conc. } \\
(\mathrm{ml} / \mathrm{kg}) \%\end{array}$} & \multicolumn{5}{|c|}{ (\%)Adult mortality after indicated days } & \multirow{2}{*}{$\begin{array}{l}\text { No. of } F_{1} \text { progeny } \\
\text { after } 60 \text { days }\end{array}$} & \multirow{2}{*}{$\begin{array}{l}\text { \% reduction in } \\
\mathrm{F}_{1} \text { progeny }\end{array}$} \\
\hline & & 2 & 3 & 5 & 7 & 10 & & \\
\hline \multirow{4}{*}{ Clove oil } & 8 & $91.6 \pm 3.3$ & $100 \pm 0$ & $100 \pm 0$ & $100 \pm 0$ & $100 \pm 0$ & 0 & $100 \%$ \\
\hline & 6 & $86.6 \pm 3.3$ & $100 \pm 0$ & $100 \pm 0$ & $100 \pm 0$ & $100 \pm 0$ & 0 & $100 \%$ \\
\hline & 4 & $85 \pm 5.78$ & $100 \pm 0$ & $100 \pm 0$ & $100 \pm 0$ & $100 \pm 0$ & 0 & $100 \%$ \\
\hline & 2 & $21.6 \pm 4.4$ & $100 \pm 0$ & $100 \pm 0$ & $100 \pm 0$ & $100 \pm 0$ & 2 & $97.5 \%$ \\
\hline \multicolumn{2}{|c|}{ Control } & 0 & 0 & 0 & 0 & 0 & 83 & \\
\hline \multirow{5}{*}{$\begin{array}{c}\text { Clove } \\
\text { petroleum } \\
\text { ether extract }\end{array}$} & 3 & $100 \pm 0$ & $100 \pm 0$ & $100 \pm 0$ & $100 \pm 0$ & $100 \pm 0$ & 0 & $100 \%$ \\
\hline & 2 & $100 \pm 0$ & $100 \pm 0$ & $100 \pm 0$ & $100 \pm 0$ & $100 \pm 0$ & 0 & $100 \%$ \\
\hline & 1 & $91.6 \pm 4.4$ & $98.3 \pm 1.6$ & $98.3 \pm 1.6$ & $100 \pm 0$ & $100 \pm 0$ & 0 & $100 \%$ \\
\hline & 0.5 & $75 \pm 10$ & $85 \pm 7.6$ & $91.6 \pm 4.4$ & $91.6 \pm 4.4$ & $91.6 \pm 4.4$ & 0 & $100 \%$ \\
\hline & 0.25 & $61.6 \pm 9.2$ & $80 \pm 8.6$ & $85 \pm 5.7$ & $88.3 \pm 4.4$ & $88.3 \pm 4.4$ & 3 & $96 \%$ \\
\hline \multicolumn{2}{|c|}{ Control } & 0 & 0 & 0 & 0 & 0 & 77 & \\
\hline
\end{tabular}

Table (2): Toxicity of both clove oil and extract on T. casteneum adults infesting wheat seeds

\begin{tabular}{|c|c|c|c|c|c|c|c|c|}
\hline \multirow{2}{*}{$\begin{array}{c}\text { Tested } \\
\text { material }\end{array}$} & \multirow{2}{*}{$\begin{array}{l}\text { Conc. } \\
(\mathrm{ml} / \mathrm{kg}) \%\end{array}$} & \multicolumn{5}{|c|}{ (\%)Adult mortality after indicated days } & \multirow{2}{*}{$\begin{array}{l}F_{1} \text { progeny } \\
\text { after } 60 \text { days }\end{array}$} & \multirow{2}{*}{$\begin{array}{l}\% \text { reduction in } \\
\mathrm{F}_{1} \text { progeny }\end{array}$} \\
\hline & & 2 & 3 & 5 & 7 & 10 & & \\
\hline \multirow{4}{*}{ Clove oil } & 8 & $0 \pm 0$ & $0 \pm 0$ & $1.3 \pm 3.3$ & $8.3 \pm 4.4$ & $18.3 \pm 4.4$ & 0 & $100 \%$ \\
\hline & 6 & $0 \pm 0$ & $0 \pm 0$ & $1.6 \pm 1.6$ & $1.6 \pm 1.6$ & $10 \pm 2.9$ & 8 & $89 \%$ \\
\hline & 4 & $0 \pm 0$ & $0 \pm 0$ & $0 \pm 0$ & $0 \pm 0$ & $3.3 \pm 1.6$ & 13 & $82.4 \%$ \\
\hline & 2 & $0 \pm 0$ & $0 \pm 0$ & $0 \pm 0$ & $0 \pm 0$ & $1.6 \pm 1.6$ & 21 & $71.6 \%$ \\
\hline \multicolumn{2}{|c|}{ Control } & 0 & 0 & 0 & 0 & 0 & \multicolumn{2}{|c|}{74} \\
\hline \multirow{4}{*}{$\begin{array}{l}\text { Clove } \\
\text { petroleum } \\
\text { ether extract }\end{array}$} & 3 & $31.6 \pm 6$ & $41.6 \pm 6$ & $55 \pm 7.6$ & $55 \pm 7.6$ & $70 \pm 10.4$ & 0 & $100 \%$ \\
\hline & 2 & $6.6 \pm 3.3$ & $13.3 \pm 4.4$ & $15 \pm 5$ & $16.6 \pm 6$ & $21.6 \pm 4.4$ & 0 & $100 \%$ \\
\hline & 1 & $3.3 \pm 3.3$ & $5 \pm 2.8$ & $5 \pm 2.8$ & $6.6 \pm 1.6$ & $13.3 \pm 4.4$ & 0 & $100 \%$ \\
\hline & 0.5 & $0 \pm 0$ & $0 \pm 0$ & $1.6 \pm 1.6$ & $3.3 \pm 3.3$ & $8.3 \pm 3.3$ & 14 & $78.5 \%$ \\
\hline \multicolumn{2}{|c|}{ Control } & 0 & 0 & 0 & 0 & 0 & \multicolumn{2}{|c|}{65} \\
\hline
\end{tabular}

Table (3): Toxicity of both clove oil and extract on C.maculatus adults infesting cowpea seeds.

\begin{tabular}{|c|c|c|c|c|c|c|c|c|}
\hline \multirow[b]{2}{*}{$\begin{array}{l}\text { Tested } \\
\text { material }\end{array}$} & \multirow[b]{2}{*}{$\begin{array}{l}\text { Conc. } \\
(\mathrm{ml} / \mathrm{kg}) \%\end{array}$} & \multicolumn{5}{|c|}{ (\%)Adult mortality after indicated days } & \multirow[b]{2}{*}{$\begin{array}{l}F_{1} \text { progeny } \\
\text { after } 27 \text { days }\end{array}$} & \multirow{2}{*}{$\begin{array}{c}\% \\
\text { reduction } \\
\text { in } F_{1} \\
\text { progeny }\end{array}$} \\
\hline & & 1 & 2 & 3 & 4 & 5 & & \\
\hline \multirow{4}{*}{ Clove oil } & 8 & $100 \pm 0$ & $100 \pm 0$ & $100 \pm 0$ & $100 \pm 0$ & $100 \pm 0$ & 0 & $100 \%$ \\
\hline & 6 & $100 \pm 0$ & $100 \pm 0$ & $100 \pm 0$ & $100 \pm 0$ & $100 \pm 0$ & 0 & $100 \%$ \\
\hline & 4 & $100 \pm 0$ & $100 \pm 0$ & $100 \pm 0$ & $100 \pm 0$ & $100 \pm 0$ & 0 & $100 \%$ \\
\hline & 2 & $83.3 \pm 4.4$ & $91.6 \pm 3.3$ & $93.3 \pm 1.7$ & $98.3 \pm 1.7$ & $98.3 \pm 1.7$ & 0 & $100 \%$ \\
\hline Control & & 0 & 0 & 0 & 0 & 0 & \multicolumn{2}{|c|}{88} \\
\hline \multirow{6}{*}{$\begin{array}{l}\text { Clove } \\
\text { petroleum } \\
\text { ether extract }\end{array}$} & 3 & $100 \pm 0$ & $100 \pm 0$ & $100 \pm 0$ & $100 \pm 0$ & $100 \pm 0$ & 0 & $100 \%$ \\
\hline & 2 & $100 \pm 0$ & $100 \pm 0$ & $100 \pm 0$ & $100 \pm 0$ & $100 \pm 0$ & 0 & $100 \%$ \\
\hline & 1 & $86.6 \pm 6$ & $91.6 \pm 4.4$ & $95 \pm 2.8$ & $95 \pm 2.8$ & $96.6 \pm 1.6$ & 0 & $100 \%$ \\
\hline & 0.5 & $70 \pm 7.6$ & $81.6 \pm 8.3$ & $85 \pm 7.6$ & $86.6 \pm 6$ & $90 \pm 7.6$ & 0 & $100 \%$ \\
\hline & 0.25 & $51.6 \pm 7$ & $61.6 \pm 6$ & $73.3 \pm 6$ & $75 \pm 5.7$ & $76.6 \pm 7$ & 0 & $100 \%$ \\
\hline & 0.125 & $21.6 \pm 7$ & $43.3 \pm 6$ & $58.3 \pm 13$ & $63.3 \pm 10$ & $71.6 \pm 8.3$ & 0 & $100 \%$ \\
\hline ontrol & & 0 & 0 & 0 & 0 & 0 & 138 & \\
\hline
\end{tabular}

Table (4): Toxicity of both clove oil and extract on T. putrescentiae adults infesting wheat seeds.

\begin{tabular}{lccccc}
\hline \multirow{2}{*}{ Tested material } & $\begin{array}{c}\text { Conc. } \\
(\mathrm{ml} / \mathrm{kg}) \%\end{array}$ & \multicolumn{5}{c}{ (\%)Adult mortality after indicated days } \\
\cline { 2 - 6 } Clove oil & 2 & $76.6 \pm 3.3$ & $100 \pm 0$ & 5 & $100 \pm 0$ \\
& 1 & $66.6 \pm 6.6$ & $96.6 \pm 3.3$ & $100 \pm 0$ & $100 \pm 0$ \\
\cline { 2 - 6 } & 0.5 & $53.3 \pm 8.7$ & $76.6 \pm 12$ & $80 \pm 10$ & $90 \pm 5.7$ \\
\cline { 2 - 6 } & 0.25 & $46.6 \pm 6.6$ & $50 \pm 5.7$ & $60 \pm 5.7$ & $60 \pm 5.7$ \\
\hline Control & & 0 & 0 & 0 & 0 \\
\hline \multirow{3}{*}{$\begin{array}{l}\text { Clove petroleum } \\
\text { ether extract }\end{array}$} & $3 \%$ & $75 \pm 0.8$ & $90 \pm 0.57$ & $100 \pm 0$ & $100 \pm 0$ \\
\cline { 2 - 6 } & $2 \%$ & $35 \pm 8.82$ & $70 \pm 5.7$ & $80 \pm 0$ & $90 \pm 5.7$ \\
\cline { 2 - 6 } & $1 \%$ & $10 \pm 8.8$ & $30 \pm 5.7$ & $60 \pm 5.7$ & $70 \pm 5.7$ \\
\hline control & $0.5 \%$ & $0 \pm 0$ & $23.3 \pm 3.3$ & $50 \pm 5.7$ & $60 \pm 0$ \\
\hline
\end{tabular}


Table (5): Toxicity of both clove oil and extract on D. farinae adults infesting wheat seeds

\begin{tabular}{|c|c|c|c|c|c|}
\hline \multirow{2}{*}{ Tested material } & \multirow{2}{*}{$\begin{array}{c}\text { Conc. } \\
(\mathrm{ml} / \mathrm{kg}) \%\end{array}$} & \multicolumn{4}{|c|}{ (\%)Adult mortality after indicated days } \\
\hline & & 1 & 3 & 5 & 7 \\
\hline \multirow{4}{*}{ Clove oil } & 2 & $10 \pm 5.7$ & $26.6 \pm 3.3$ & $33.3 \pm 6.6$ & $46.6 \pm 3.3$ \\
\hline & 1 & $6.6 \pm 6.6$ & $23.3 \pm 3.3$ & $23.3 \pm 3.3$ & $33.3 \pm 8.8$ \\
\hline & 0.5 & $3.3 \pm 3.3$ & $13.3 \pm 6.6$ & $13.3 \pm 6.6$ & $20 \pm 10$ \\
\hline & 0.25 & $3.3 \pm 3.3$ & $10 \pm 1$ & $10 \pm 1$ & $10 \pm 1$ \\
\hline \multirow[t]{2}{*}{ Control } & & 0 & 0 & 0 & 0 \\
\hline & $3 \%$ & $30 \pm 1.5$ & $93.3 \pm 3.3$ & $96.6 \pm 3.3$ & $96.6 \pm 3.3$ \\
\hline \multirow{3}{*}{$\begin{array}{l}\text { Clove petroleum } \\
\text { ether extract }\end{array}$} & $2 \%$ & $20 \pm 5.7$ & $55 \pm 8.8$ & $70 \pm 8.82$ & $77 \pm 3.33$ \\
\hline & $1 \%$ & $15 \pm 8.8$ & $40 \pm 03.3$ & $60 \pm 5.7$ & $60 \pm 5.7$ \\
\hline & $0.5 \%$ & $10 \pm 0$ & $20 \pm 3.3$ & $20 \pm 0$ & $30 \pm 5.7$ \\
\hline contr & & 0 & 0 & 0 & 0 \\
\hline
\end{tabular}

Table (6): Relative potency values of clove commercial oil on tested pest adults.

\begin{tabular}{ccccc}
\multicolumn{2}{l}{ Table (6): Relative potency values of clove comme } & Lc95 & Slope & Toxicity index (\%) \\
\hline Tested pests & Lc50 & 0.0791 & $3.7162 \pm 0.4223$ & 11.72 \\
\hline S.oryzae & 0.0286 & 1.0839 & $2.3004 \pm 0.7511$ & 1.62 \\
\hline T.casteneum & 0.2089 & 0.2112 & $0.9195 \pm 0.3555$ & 100 \\
\hline T. putrescentiae & 0.0034 & 0.3968 & $1.3158 \pm 0.3930$ & 15.45 \\
\hline D. farinae & 0.0223 & &
\end{tabular}

Table (7): Relative potency values of clove petroleum ether extract on tested pest adults.

\begin{tabular}{ccccc}
\hline Tested pests & Lc50 & Lc95 & Slope & Toxicity index (\%) \\
\hline S.oryzae & 0.0617 & 0.6186 & $1.6427 \pm 0.6303$ & 100 \\
\hline C.maculatus & 0.0927 & 1.2118 & $1.4700 \pm 0.2829$ & 66.6 \\
\hline T.casteneum & 2.6266 & 12.8426 & $2.3865 \pm 0.3698$ & 2.36 \\
\hline T. putrescentiae & 1.198 & 5.2277 & $2.5708 \pm 0.4543$ & 5.17 \\
\hline D. farinae & 0.8357 & 3.944 & $2.4410 \pm 0.4582$ & 7.42 \\
\hline
\end{tabular}

Toxicity index = LC50 of the most effective pesticide/ LC50 of the tested pesticide $\mathrm{x} 10$

most toxic to $D$. farinae adults was methyleugenol (0.94 microg/cm(2)) followed by isoeugenol (5.17 microg/cm(2)), eugenol (5.47 microg/cm(2)), benzyl benzoate $(9.22$ microg $/ \mathrm{cm}(2))$, and acetyleugenol (14.16 microg/cm(2)). Eugenol and its congeners merit further study as potential house dust mite control agents or as lead compounds.

The advantages of using essential oils as grain protectants are: (1) they can be easily extracted by steam distillation or chemical solvents; (2) they have very low toxicity to mammals since they are popular spices consumed by people in various parts of the world; and (3) the essential oils are volatile and this can be potentially used as fumigants.

In conclusion: clove extract was powerful than commercial oil in controlling stored grain pests especially those known to have high tolerance.

\section{2) DATA ANALYSIS}

The probit statistics estimate of $\mathrm{LC}_{50}, \mathrm{LC}_{95}$ and the slope of regression lines of clove commercial oil and extract are presented in Tables $(6 \& 7)$ and Figs. (1 \& 2).

From probit analysis, it was found that the highest toxicity of commercial oil was with $T$. putrescentiae and the lowest with T. casteneum; while the highest toxicity of clove extract was with S.oryzae and the lowest was with T.casteneum.

When probit regression lines of both clove oil and extract against all tested pests were calculated, they showed a linear relationship between mortality percentage and concentration.

\section{3) RESIDUAL TOXICITY STUDIES: \\ 3-a) PERSISTANCE TESTS:}

The residual effect of clove petroleum ether extract was experimented to evaluate its efficacy during storage for 10 weeks. The toxicity was tested every week. The used concentrations were the lowest values of $\mathrm{LC}_{95}$. i.e., 0.77 and 0.62 $(\mathrm{w} / \mathrm{w})$ with $C$. maculatus and $S$. oryzae, respectively.

The obtained results revealed that $\mathrm{LC}_{95}$ concentration of clove buds extract was very 


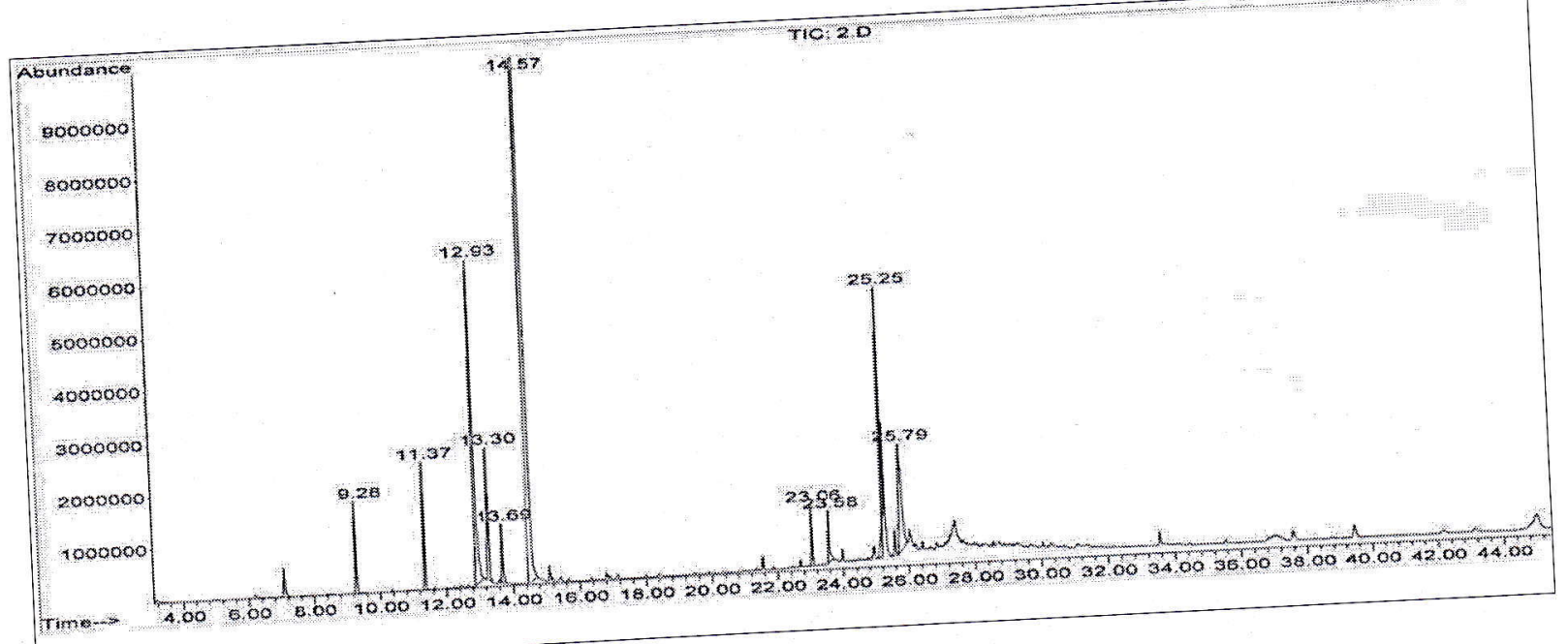

Fig. (1): GC/MS analysis of commercial clove oil.

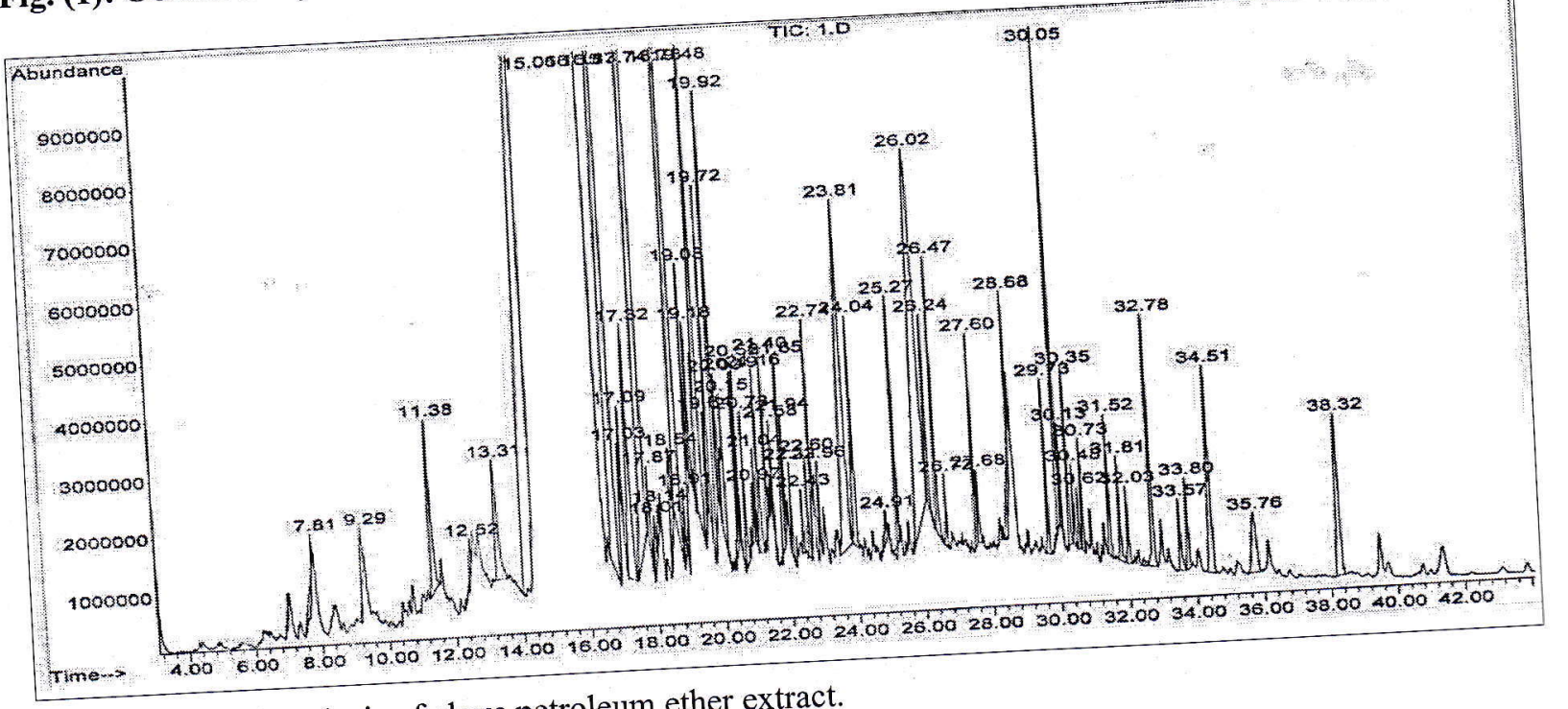

Fig. (2): GC/MS analysis of clove petroleum ether extract.

Table (8): Effect of clove extract at $\mathrm{LC}_{95}$ on germination of treated cowpea and wheat after 2 storage periods.

\begin{tabular}{ccc}
\hline \multirow{2}{*}{ \% germination after } & \multicolumn{2}{c}{ Seeds } \\
\cline { 2 - 3 } & Wheat & Cowpea \\
\hline 1 day & $96.6 \%$ & $98.3 \%$ \\
\hline Control & $98.3 \%$ & $100 \%$ \\
\hline significance & $\mathrm{ns}$ & $\mathrm{ns}$ \\
\hline LSD 5\% & 1.3 & 0.93 \\
\hline 8 weeks & $83.3 \%$ & $86.6 \%$ \\
\hline Control & $96.6 \%$ & $100 \%$ \\
\hline significance & $*$ & $*$ \\
\hline LSD 5\% & 2.06 & 1.3 \\
\hline
\end{tabular}

powerful in protecting grains during storage up to 10 weeks. Mortality $(\%)$ and $\%$ reduction $F_{1}$ - progeny of the two tested insects were $100 \%$ during the experimental period. This could be very useful to decrease economic losses caused by pests attacking.
Sumadi et al., 2010 studied the effect of clove oil dosage on controlling storage beetle C. maculatus F., and maintaining seed quality including seed viability and seed vigor of two soybean after three months storage duration and found that dosage of clove oil 5 $\mathrm{mL} / \mathrm{kg}$ soybean seed showed better effect on suppression of storage beetle and maintaining seed viability and vigor.

3-b) SEEDS GERMINATION TESTS:

One of the important points when using plant extracts in controlling pests is if it has harmful effect on germination, this experiment was carried out to answer this question.

Germination (\%) recorded in Table (8) was subject to analysis of variance and differences using anova test (a computer program costate). Mean values were adjusted by Duncan's Multiple Range test Duncan (1951) at $0.05 \%$ level of significance with Statistical software version 6.3.0.3. Data showed that 
clove extract had low significant effect on germination (\%) of both cowpea and wheat seeds after 10 weeks of storage comparing with untreated seeds.

In conclusion: clove extract is a powerful protectant for cereals and legumes seeds during storage against different pests with low significance on germination.

The previous results are incompatible with that of Mazzafera (2003) observed that clove ethanolic extract and pure eugenol, the major constituent of clove oil had an allelopathic effect on the germination of several seeds, as well as that some of these seedlings sprayed with the clove extract showed a lower dry mass accumulation. Kritzenger et al., 2002 tested the antifungal activity of clove oil on storage fungi associated with cowpea seeds and found that the oil has no harmful effect on the germination and emergence of cowpea seeds.

\section{4) GC/MS CHROMATOGRAM ANALYSIS:}

The chemical constituents of clove commercial oil and petroleum ether extract89were analysed by GC/MS technique. The components were characterized by comparing their mass spectra with those of their analogous reported by the NIST and WILEY libraries and with the authentic spectra (Adams, 1995).

\section{3-1) Identification of clove extract components by using GC/MS technique:}

The GC chromatogram showed 10 peaks corresponding to 10 compounds. The main constituents were eugenol $(50.58 \%)$, cinnamaldehyde $(15.72 \%)$ and linoleic acid $(9.52 \%)$.

The GC chromatogram showed 24 peaks corresponding to 24 compounds. The main constituents were eugenol $(37.43 \%)$ eugenol acetate $(11.47 \%)$, caryophellene $(10.44 \%)$, linoleic acid $(9.42 \%)$ and caryophellene oxide $(8.58 \%)$.

Previous results showed that eugenol (\%) in commercial oil was higher than that in clove extract and this is may be due to that commercial oil was artificially manufactured based on eugenol as it is the main constituent in clove.

These results are compatible with those of AboEl-Saad et al., 2011 who found that essential oil from clove buds (Syzygium aromaticum) was extracted using petroleum ether in Soxhlet apparatus. The resultant oil contained eugenol (48.92\%), caryophyllene (18.55\%), $\alpha$-caryophyllene $(3.25 \%)$, eugenol acetate (23\%), cis-13-docosenamide (3.21\%), presenting more than $96 \%$ of the oil. Nazrul et al., 2010 analyzed essential oil obtained by hydrodistillation from dry buds of Syzigium caryophyllatum by Gas Chromatography Mass
Spectrometry (GC-MS). Thirty one components were identified in bud oil with the main components being eugenol (49.7\%), caryophyllene (18.9\%), benzene,1ethyl-3-nitro $(11.1 \%)$ and benzoic acid,3-(1methylethyl) (8.9\%). Nassar et al., 2007 recorded sixteen volatile compounds identified from the nhexane extract of the buds of Syzygium aromaticum by using gas chromatography-mass spectroscopy (GC-MS). The major components were eugenol $(71.56 \%)$ and eugenol acetate $(8.99 \%)$.

\section{REFERENCES}

Abbot, W.J. 1925. A method for computing the effectiveness of an insecticide .J. Econ. Entomol, 18: 265-276.

Abd El-Salam, A., M. E. 2010. Fumigant toxicity of seven essential oils against the cowpea weevil, Callosobruchus maculatus (F.) and the rice weevil, Sitophilus oryzae (L.). Egypt. Acad. J. biolog. Sci., 2 (1): 1 - 6.

Abo-El-Saad, M. M.; Al Ajlan, A. M.; Al-Eid, M. A. and Bou-Khowh, I. A. 2011. Repellent and Fumigant Effects of Essential Oil from Clove Buds Syzygium aromaticum L. against Tribolium castaneum (Herbest) (Coleoptera: Tenebrionidae), Journal of Agricultural Science and Technology A1: 613-620.

Adams, R. 1995. Text book of identification of essential oil components gas chromatography/ mass spectroscopy. $2^{\text {nd }}$ ed. 46:1460.

Alma, M.; Hakkı, M. E.; Siegfrie, N. and Hubert, K. 2007. Chemical composition and content of essential oil from the bud of cultivate clove (Syzygium aromaticum L.). BioResources 2(2): 265-269.

Ayoola1, G. A.; Lawore1, F. M; Adelowotan, T.; Aibinu, I. E. ; Adenipekun, E. ; Coker1, H. A. B. and Odugbemi, T. O. 2008. Chemical analysis and antimicrobial activity of the essential oil of Syzigium aromaticum (clove). African Journal of Microbiology Research,2:162-166.

Dimetry, N. Z.; El-Gengaih, I. S. and Abd El- Salam, A. M. E. 2007. Protection of stored cowpea from Callosobruchus maculates (F.) attack by some plant extract formulations in different storage sacks. Herpa Polonica, 53(1): 71-84.

Duncan, D. B. 1951. A significance test for differences between ranked treatments in an analysis of variance. Virginia Journal of Science, 2:171-189.

El-Lakwah, F. A.; Darwish, A. A. and Halawa, Z. A. 1996. Toxic effect of extracts and powders of some plants against the cowpea beetle, Callosobruchus maculatus (F). Annals of Agricultural Science, Moshtohor, 34(4): 1849-1859. 
Finney, D. J. 1971. Probit analysis. A Statistical Treatment of The Sigmoid Response Curve. $7^{\text {th }}$ Ed., Cambridge Univ. press, England.

Fouad, H. A. 2013a. Effect of five essential oils as repellents against the cowpea beetle, Callosobruchus maculatus (F.). Bull. Env. Pharmacol. Life Sci., 2 (5).

Fouad, H. A. 2013 b. Bioactivity of five essential oils against bruchidius 90oleoptera (bohemann, 1833), not sci ole, 5(3):354-359.

Gurdip, S. and Sumitra, M. 2005. Antimicrobial, antifungal and insecticidal investigations on essential oils. NPR, 4(3): 179-192.

Khalequzzaman, M. and Rumu, S. N. 2010. Toxicity of prirmiphos-methyl and three essential oils, alone and in combination against Callosobruchus maculatus (F.). Univ. J. Zool. Rajshahi. Univ., 28: $1-5$.

Kim, E. H.; Kim, H. K. and Ahn, Y. J. 2003a. Acaricidal activity of clove bud oil compounds against Dermatophagoides farinae and Dermatophagoides pteronyssinus (Acari: Pyroglyphidae). J. Agric. Food Chem., 51(4):885-889.

Kim, E. H.; Kim, H. K.; Choi, D. H. and Ahn, Y. J. 2003b. Acaricidal activity of clove [Syzygium aromaticum] bud oil compounds against Tyrophagus putrescentiae (Acari: Acaridae). Applied Entomology and Zoology, 38(2): 261-266.

Kritzinger, Q.; Aveling, T. A. S. and Marasas, W. F. O. 2002. Effect of essential plant oils on storage fungi, germination and emergence of cowpea seeds. Seed Sci, Technol, 30: 609-619.

Kwon, P. and Sang-Chul, S. 2005. Fumigant Activity of plant essential oils and components from garlic (Allium sativum) and clove bud (Eugenia caryophyllata) oils against the Japanese termite (Reticulitermes speratus), J. Agric. Food Chem., 53 (11): 4388-4392.

Lee, S. E.; Lee, B. H.; Choi, W. S. and Park, B. S. 2001. Fumigant toxicity of essential oils and their constituents compounds towards the rice weevil, Sitophilus oryzae (L). Crop Protection, 20: 317-320.

Li, Y. D. 2004. Agricultural Entomology (Southern Edition). China Agriculture Press, Beijing, pp. 369.

Mahdi, A. S. H. and Khaladur, R. M. D. 2008. Insecticidal effect of some spices on Callosobruchus maculatus (Fabricius) in black gram seeds, Univ. j. zool. Rajshahi Univ., 27:47-50.

Mahfuz and Khalequzzaman, M. 2007. Contact and fumigant toxicity of essential oils against Callosobruchus maculatus. Univ. J. Zool.
Rajshahi Univ., 26: 63-66.

Mazzafera, P. 2003. Allellopathic effects of the alcoholic extract of clove and eugenol. Rev. bras. Bot., 26(2):231-238.

Mishra, B. B.; Tripathi, S. P. and Tripathi, C. P. M. 2014. Chronic activity of plant volatiles essential oils in management of rice weevil Sitophilus oryzae (Coleoptera: Curculionidae). Journal of Entomology, 11: 78-86.

Mondal, M. and Khalequzzaman, M. 2006. Toxicity of essential oils against red flour beetle, Tribolium oleopter (Herbst) (90Coleopteran: tenebrionidae). J. bio-sci., 14: 43-48.

Nassar, M. I.; Gaara, A. H.; El-Ghorab, A. H.; Farrag, H. A.; Hui, S.; Enamul, H. and Mabry,T. J. 2007. Chemical constituents of clove (Syzygium aromaticum, Fam. Myrtaceae) and their antioxidant activity, Rev. Latinoamer. Quím., 35(3):47-57.

Nazrul, M. D.; Islam, B.; Jaripa B.; Nemai C. N. and Farhana A. 2010. Constituents of the essential oil from leaves and buds of clove (Syzigium caryophyllatum (L.) Alston) . African Journal of Plant Science, 4(11), pp. 451-454.

Park, I. K.; Lee, S. G.; Choi, D. H.; Park, J. D. and Ahn, Y. J. 2003. Insecticidal activities of constituents identified in the essential oil from leaves of Chamaecyparis obtuse against Callosobruchus chinensis (L.) and Sitophilus oryzae (L.). Journal Stored Product Research 39: 375-384.

Pumnuan, J. and Insung, A. 2011. Effectiveness of essential oils of medicinal plants against stored product mite, Suidasia pontifica Oudemans, IV International Conference Postharvest Unlimited.

Sabbour, M. M. and Abd-El-Aziz, S. E. 2009. Efficacy of some bioinsecticides against Bruchidius incarnatus (boh.) (Coleoptera: Bruchidae) infestation during storage. Journal of Plant Protection Research, 50(1):28-33.

Su, H. C. F. 1985. Laboratory study on effects of Anetium graveoleus seeds on four species of stored product insects. J. Econ. Entomol., 78:451453.

Sumadi, N., A. and Amalia, A. 2010. The effect of clove oil dosage on population of Callosobruchus maculatus F., seed viability and vigor of two soybean $\mathrm{cv}$ after three months storage duration. International Seminar Biotechnology, Padjadjaran University October $18-20^{\text {th }}: 48-60$.

Zeng, L.; Lao, C. Z.; Cen, Y. J. and Liang, G.W. 2010. Study on the insecticidal activity compounds of the essential oil from Syzygium aromaticum against stored grain insect pests. $10^{\text {th }}$ International Working Conference on Stored Product Protection. Julius-Kühn-Archiv, pp: 425. 